\title{
Message of the 10th Assembly of the World Council of Churches, Busan 2013: Join the Pilgrimage of Justice and Peace
}

By the tender mercy of our God, the dawn from on high will break upon us, to give light to those who sit in darkness and in the shadow of death, to guide our feet into the way ofpeace.

Luke 1:78-79

\section{Dear Sisters and Brothers, we greet you in the name of Christ.}

We gathered in the Republic of Korea at the 10th Assembly of the World Council of Churches (30 October-8 November 2013). Coming from 345 member churches of the fellowship and from partner organizations in the ecumenical movement, we joined in prayer, shared stories from our local communities and took to heart strong messages of agony and hope. We are thankful for the many engaging statements released. Our common pilgrimage traced the theme "God of life, lead us to justice and peace."

In the city of Busan, we journeyed together on a road of transformation - we pray that as we are being transformed ourselves, God will make us instruments of peace. Many of us travelled to other parts of Korea where we witnessed the open wounds of a society torn by conflict and division. How necessary is justice for peace; reconciliation for healing; and a change of heart for the world to be made whole!We were encouraged by the active and committed churches we encountered; their work bears bountiful fruit. We share our experience of the search for unity in Korea as a sign of hope in the world. This is not the only land where people live divided, in poverty and richness, happiness and violence, welfare and war. We are not allowed to close our eyes to harsh realities or to rest our hands from God's transforming work. As a fellowship, theWorld Council of Churches stands in solidarity with the people and the churches in the Korean peninsula, and with all who strive for justice and peace.

God our Creator is the source of all life. In the love of Jesus Christ and by the mercy of the Holy Spirit we, as a communion of the children of God, move together towards the fulfillment of the Kingdom. Seeking grace from God we are called, in our diversity, to be just stewards of God's Creation. This is the vision of the New Heaven and Earth, where Christ will "fill all in all" (Eph 1.23). 
We live in a time of global crises. Economic, ecological, socio-political and spiritual challenges confront us. In darkness and in the shadow of death, in suffering and persecution, how precious is the gift of hope from the Risen Lord! By the flame of the Spirit in our hearts, we pray to Christ to brighten the world: for his light to turn our whole beings to caring for the whole of creation and to affirm that all people are created in God's image. Listening to voices that often come from the margins, let us all share lessons of hope and perseverance. Let us recommit ourselves to work for liberation and to act in solidarity. May the illuminating Word of God guide us on our journey.

We intend to move together. Challenged by our experiences in Busan, we challenge all people of good will to engage their God-given gifts in transforming actions.

This Assembly calls you to join us in pilgrimage.

May the churches be communities of healing and compassion, and may we seed the Good News so that justice will grow and God's deep peace rest on the world.

Blessed are they who observe justice, who do righteousness at all times!

Psalm 106:3

God of life, lead us to justice and peace! 